\title{
Modelling and thermodynamic analysis of ejector flow for application at design and off design operating conditions in an ejector air conditioner
}

\author{
AnoopKumar.M', Devendrakumar Patel ${ }^{\mathrm{b}}$ \\ ${ }^{\mathrm{a}}$ Research Scholar, ${ }^{\mathrm{b}}$ Associate Professor \\ ${ }^{\mathbf{a}, \mathbf{b}}$ School of Mechanical engineering, VIT University, Vellore, India
}

Article History: Received: 10 November 2020; Revised 12 January 2021 Accepted: 27 January 2021; Published online: 5 April 2021

\begin{abstract}
Ejector flow in an ejector air conditioning system using R245fa is analysed for entrainment ratio and potential refrigeration effect, at varying temperature and heat input conditions in the generator ranging from $60 \square \mathrm{C}$ to $100 \square \mathrm{C}$ and $2 \mathrm{~kW}$ to $5 \mathrm{~kW}$ respectively. The effect of varying generator temperature in cooling capacity of the system when the vapour ejectoris operating at design evaporator and condenser temperatures of $10 \square \mathrm{C}$ and $35 \square \mathrm{C}$ respectively is investigated. The mathematical model of the vapour ejector with optimum area ratio is developed and validated. A critical entrainment ratio of 0.385 is obtained corresponding to generator temperature of $100 \square \mathrm{C}$. When the generator temperature is varied from $60 \square \mathrm{C}$ to $100 \square \mathrm{C}$, the cooling capacity range from $0.3 \mathrm{~kW}$ at generator heat input of $2 \mathrm{~kW}$ to $1.78 \mathrm{~kW}$ at $5 \mathrm{~kW}$ heat input. Further, the operation of the system is analysed for off design operating condition corresponding to reduced heat input rate in the generator. In that case the state of primary refrigerant flow in ejector inlet will be two phase and a mathematical model for two-phase ejector flow is developed and validated. Ejector flow analysis revealed the minimum quality of flow at ejector inlet to maintain adequate backpressure for condensation to occur range from 0.72 at $60 \square \mathrm{C}$ to 0.22 at $100 \square \mathrm{C}$. The correspading refrigeration refrigeration effect produced is less than the respective designed operation value byits $12.2 \%$ to $8 \%$. Further, analysis of the system shows that at least $7 \mathrm{~kW}$ heat input at $100 \square \mathrm{C}$ is required to produce 1 ton of cooling effect
\end{abstract}

Keywords:

\section{Introduction}

Ejector refrigeration system can be employed for summer cooling air-conditioning systems to produce refrigerationeffect to the tune of $10^{\circ} \mathrm{C}$. The low grade heat like solar thermal energy can be utilized to produce the motive flow for the ejector[1-3]. Ejectors being simple and compact flow devices which can entrain and compress a secondary flow by use of expansion energy of a primary flow is used to compress the refrigerant vapour from the evaporator. Thus it can be used to assist or replace the mechanical compressor in a vapour compression refrigeration system [2]. However ejector application is limited in commercial refrigeration industry owing to many of the constrains that is inherent to ejector operation in a practical application like domestic air conditioning system. The main drawback that hinder their wide spread usage is very poor performance at off design operating conditions[1-4]. For a given application there is an optimum geometrical design of the ejector considering the operating variables like the working fluid, the temperatures at generator, evaporator and the condenser as well as the amount of heat input[3]. This geometry is not scalable in terms of the operating variables. So variation in any of these parameters in actual operating environment will lead to poor ejector operation and inadequate refrigeration effect produced. Additionally they have quite low COP typically in the range of 0.1 to 0.6 that demands a large quantity of the heat input[1,5]. The practicality of a ejector air-conditioning system for domestic application is analysed in this paper. The system is designed to use solar thermal heat in its generator. It is desired to know the refrigeration effect produced with a nominal heat input in the range of 2 to $5 \mathrm{~kW}$ within the temperature range of $60^{\circ} \mathrm{C}$ to $100^{\circ} \mathrm{C}$. In addition there is more chance of the system working with lesser heat input rate in the generator than the design value as the solar irradiation fluctuates. The performance analysis at under designed heat input values which is seldom done previously is also investigated.

Giorgio Besagniet.al[1] gives a detailed and arranged review of various ejector and ejector assisted refrigeration systems in terms of configuration, working fluid, operating conditions etc. It is given that the solar powered ejector refrigeration system using $\mathrm{R} 245 \mathrm{fa}$ investigated experimentally under the temperature ranges of $\mathrm{T}_{\mathrm{g}}$ equal to $90^{\circ} \mathrm{C}-110^{\circ} \mathrm{C}, \mathrm{T}_{\mathrm{e}}$ equal to $20^{\circ} \mathrm{C}$ and $\mathrm{T}_{\mathrm{c}}$ equal to $35^{\circ} \mathrm{C}-40^{\circ} \mathrm{C}$, the $\mathrm{COP}$ is in the range of 0.2 to 0.22 with cooling capacity of $10.5 \mathrm{~kW}$. Also they comprehended that solar collector area requirement reported for the various theoretical and experimental studies range from $15 \mathrm{~m}^{2}$ to $70 \mathrm{~m}^{2}$ depending on cooling capacity and operating conditions, which is quite large for a domestic air conditioner application.K.O. Shestopalov et.al [3,4] designed and analysed experimentally a ejector refrigeration system using R245fa with cooling capacity $12 \mathrm{~kW}$. 
They concluded that ejector system performance strongly depends on the operating conditions, ejector component efficiencies and the working fluid. For instance it is reported that the experimental critical values of entrainment ratio for cylindrical mixing chamber ejector is 0.241 at $\mathrm{T}_{\mathrm{g}}=90^{\circ} \mathrm{C}, \mathrm{T}_{\mathrm{e}}=8^{\circ} \mathrm{C}$ and $\mathrm{T}_{\mathrm{c}}{ }^{*}=34.7^{\circ} \mathrm{C}$ and that for conical cylindrical mixing chamber ejector is 0.355 .The corresponding COP values are 0.186 and 0.27 respectively. Huang Wang et.al[6] analysed a solar ejector cooling system incorporated with a multifunction generator with $\mathrm{R} 141 \mathrm{~b}$ as the working fluid. The multifunctional generator eliminates the need of a mechanical pump in the system. It is reported that system could produce $0.75 \mathrm{~kW}$ cooling capacity with a COP of 0.225 working under $\mathrm{Tg}=90^{\circ} \mathrm{C}, \mathrm{Tc}=37^{\circ} \mathrm{C}$ and $\mathrm{Te}=8.5^{\circ} \mathrm{C}$.SzabolcsVargaet.al[7] analysed a solar ejector air-conditioning system using water as the refrigerant. They concluded that for producing effective cooling the generator temperature should be above $90^{\circ} \mathrm{C}$, evaporator temperature should be above $10^{\circ} \mathrm{C}$ and the condenser temperature should be less than $35^{\circ} \mathrm{C}$. They also reported that the solar thermal collector area required to produce $5 \mathrm{~kW}$ cooling at generator temperature of $100^{\circ} \mathrm{C}$ is $28 \mathrm{~m}^{2}$. CuneytEzgi and Ibrahim Girgin[8]designed and thermodynamically analysed the application of a steam ejector cooling system for a naval ship. Considering $\mathrm{T}_{\mathrm{e}}=4^{\circ} \mathrm{C}$ and $\mathrm{T}_{\mathrm{c}}=50^{\circ} \mathrm{C}$, the generator pressure were varied from 2 bar to 9 bar to get entrainment ratio and COP of the system working under design condition. The mass flow rate is varied as the generator pressure increases to get saturated vapour at primary nozzle inlet. The results show that entrainment ration varies from 0.31 to 0.5 with corresponding COP range of 0.3 to 0.42 .The off design study performed is based on increasing boiler pressure over the design value of 2 bar when the system is operating with the optimized ejector with area ratio of 23.3. The results show that the COP value decreases from 0.3 to 0.6 as the boiler pressure increased from 2 bar to 9 bar.

The literature studied shows that the previous investigations on ejector systems explain their performance characteristics in a wide range of heat input rate and temperature at the generator. For a domestic ejector airconditioning system working with solar thermal heat input, the practicality of the application mostly depend on the size of the solar thermal collector. A heat input up to $5 \mathrm{~kW}$ within the temperature range of $100^{\circ} \mathrm{C}$ can be generated more practically for a domestic application and an ejector study in this range of heat input is not reported exclusively. Also in practice the solar intensity is likely to be fluctuated from the design value. In that case the generator heat input may be reduced to produce a two phase flow at primary nozzle input of the ejector. The system performance at this off design condition is not yet analysed previously. In this paper a domestic airconditioning system is analysed for the cooling produced for varying amount of heat input in the range of $2 \mathrm{~kW}$ to $5 \mathrm{~kW}$. The heat in put requirement for producing one ton ofcooling is estimated. Also its performance at off design operating condition due to lower heat input rate at the generator as explained above is analysed

\section{Working Of Ejector Air Conditioning System}

In ejector air conditioning system the cooling produced in the evaporator is by means of an ejector refrigeration cycle. Ejector refrigeration cycle is a promising method of solar thermal cooling[9-12] As mentioned earlier the ejector is a flow device which enables the expansion of a primary flow in its nozzle and there by entrain and pressurise a secondary flow and with that effect, it can be applied to replace compressor in vapour compression refrigeration cycle[2,4,13]. Figure 1 .a shows the schematic of an ejector. Figure $1 . b$ represents the ejector refrigeration cycle and figure 1.c is respective T-s diagram. The main parts of the ejector are its primary nozzle and secondary inlet port, the mixing section (section 2) and the diffuser section(section 3). The saturated refrigerant vapour produced in the generator at state 0 is allowed to expand in the ejector. This expansion produce a low pressure region at the exit of primary nozzle at state 1 shown in fig b. This will entrain the saturated vapour refrigerant from the evaporator at state 7 into the ejector mixing section. in the mixing section both the primary and the secondary streams mix exchanging energy and momentum and becomes single flow at state 2. Further shock waves occur to due to change in velocity of flow and leads to pressure increase towards the end of constant area mixing section[13]. The velocity of flow is further reduced to reach the mixed flow pressure to condenser pressure corresponding to state 3.The flow is condensed to state 4 from which a portion is pumped to generator at state 5 and the other portion is expanded to evaporator inlet at state 6.The refrigeration effect can be produced as long as there is ejector flow at with entrainment.

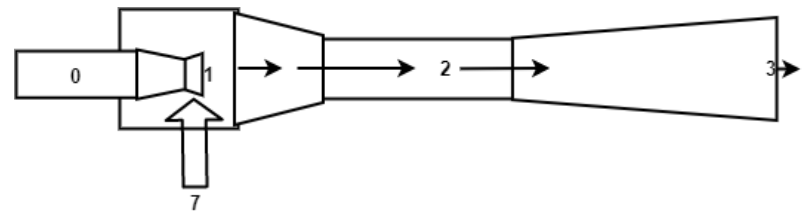

Fig 1.aThe schematic of ejector 


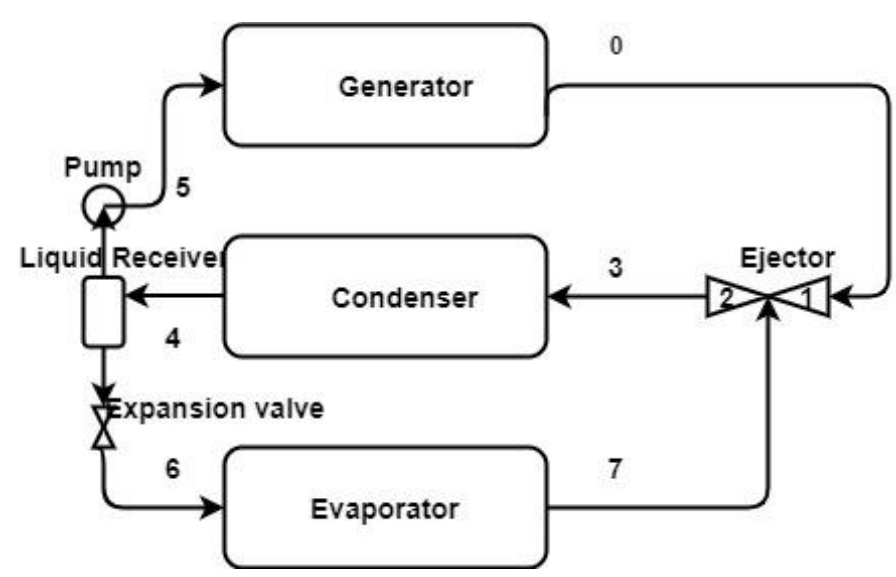

Fig 1.b Ejector refrigeration system

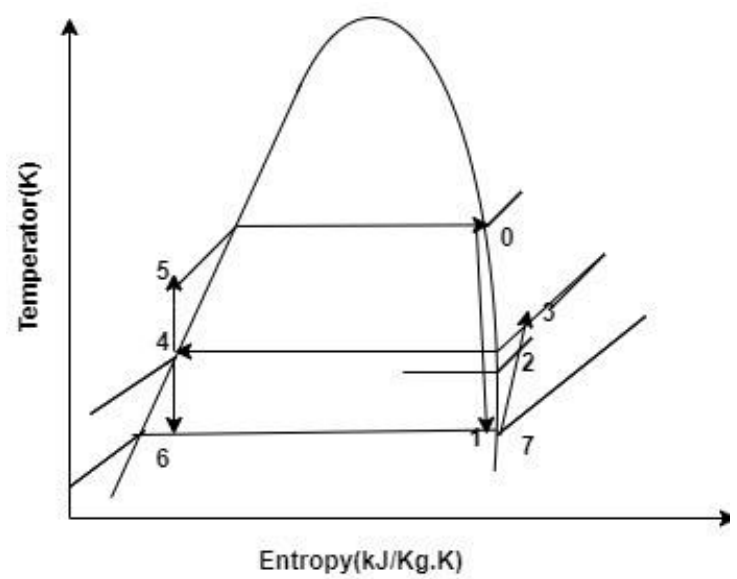

Fig.1.c- T-s diagram of ejector refrigeration cycle

This study focused on ejector air conditioning system making use of low grade heat in the range of $60^{\circ} \mathrm{C}$ to $100^{\circ} \mathrm{C}$ with generator heat transfer rate of 2 to $5 \mathrm{~kW}$.The aim is to estimate the entrainment ratio and the cooling capacity produced by the system under varying heat input rate. Accordingly the ejector is sized and analysed for the above application as detailed in section 3.The design operating conditions are given in the table 1. Selection of proper refrigerant for ejector system is important. The most desirable properties of the suitable refrigerant are a positive slop of the vapour dome which represents the dry refrigerants, relatively low pressure so that pump work and the piping design will not be tedious, high latent heat of evaporation, nontoxic, low potentials of global warming effect and ozone layer depletion. Refrigerant R $245 \mathrm{fa}$ meets many of these conditions and is selected for this application[1,3,14].

Table.1 The design conditions

\begin{tabular}{|l|l|}
\hline Energy source evaporator temperature & $10^{\circ} \mathrm{C}$ \\
\hline Condenser temperature & $35^{\circ} \mathrm{C}$ \\
\hline Refrigerant & $\mathrm{R} 245 \mathrm{fa}$ \\
\hline Generator heat input & $2 \mathrm{~kW}-5 \mathrm{~kW}$ \\
\hline Generator Temperature & $60^{\circ} \mathrm{C}-100^{\circ} \mathrm{C}$ \\
\hline
\end{tabular}

\section{Sizing And Simulation Of The Ejector}

Mathematical modelling and simulation of refrigerant ejector flow have been investigated widely[2,15-19]. Even though we have to assume the component efficiencies in this approach, it is able to predict the ejector performance in good agreement with experimental values. The mathematical formulations for modelling vapour 
ejector and that of two-phase ejector are different. In this study, the vapour ejector model is used to predict the operation at design operating conditions and the two-phase ejector model is used for prediction at off design conditions.

\subsection{Modelling the vapour ejector}

The ejector model is developed according to the procedure given by[8]. Referring to figure 1 the equations for ejector sizing and system simulation are formulated. This model is based on the optimum area ratio for the ejector for a given application. The ejector structure design mainly depends on the diameter of the mixing area. It is characterized by the area ratio, which is defined as the cross sectional area of the constant area section $\mathrm{A}_{2}$ divided by primary nozzle throat area $\mathrm{A}_{\mathrm{t}}$

$$
\emptyset=\frac{A_{2}}{A_{t}}(1)
$$

\subsubsection{Primary nozzle section}

The throat diameter of the primary nozzle can be obtained from

$$
A_{t}=\frac{m_{0}}{p_{0}} \sqrt{\frac{R T_{0}}{K}\left(\frac{K+1}{2}\right)^{K+1 / K-1}}(2)
$$

Where $\mathrm{R}$ is the gas constant and $\mathrm{K}$ is the isentropic exponent of working fluid at the ejector inlet condition. The mass flow rate though the ejector is adjusted to get saturated vapour at the primary nozzle inlet. Referring to fig $1 . b$ the following equations can be formulated.

The throat velocity $\mathrm{V}_{\mathrm{t}}$ can be calculate as

$V_{t}=\sqrt{m_{n} \times 2\left(h_{0}-h_{1 s}\right)}(3)$

efficiency of primary nozzle

$\eta_{n}=\frac{h_{0}-h_{1}}{h_{0}-h_{1 s}}(4)$

If $\mathrm{V}_{\mathrm{t}}$ is greater than the local sonic velocity given by $\mathrm{a}=\sqrt{K R T}$, we need to have converging diverging nozzle as the flow will be supersonic.

Assuming an initial velocity of $\mathrm{V}_{0}$, the inlet diameter of the nozzle can be obtained from

$$
\begin{aligned}
& \rho_{0} A_{0} V_{0}=\rho_{t} A_{t} V_{t}(5) \\
& \text { where } \frac{\rho_{0}}{\rho_{T}}=[1+(K-1) / 2]^{1 / K-1(6)}
\end{aligned}
$$

The flow rate of ejector primary flow can be calculated as

$$
m_{0}=\frac{Q_{g}}{h_{0}-h_{g}}(7)
$$

The most important parameter in ejector operation is it's entrainment ratio $\mu$. It is designed as the ratio of mass flow rate of the secondary flow to that of primary flow.

$$
\mu=\frac{m_{7}}{\dot{m}_{0}}(8)
$$

Entrainment ratio depends upon the geometry of the ejector, the working condition as well as the working fluid. Therefore there is an optimum design of the ejector for a particular application for maximum entrainment ratio

For inlet and outlet conditions of the ejector flow, the conservation of energy gives,

$$
m_{0} h_{0}+m_{7} h_{7}=\left(m_{0}+m_{7}\right) h_{3}(9)
$$

\subsubsection{Mixing section}

Conservation of mass gives

$m_{0}+m_{7}=\frac{A_{2} V_{2}}{v_{2}}$

conservation of energy gives 
$m_{0} h_{0}+m_{7} h_{7}=\left(m_{0}+m_{7}\right)\left(h_{2}+V_{2}^{2} / 2\right)$

conservation of momentum considering a mixing efficiency $\eta_{\mathrm{m}}$ gives

$\eta_{m}\left(m_{0} V_{1}+P_{7} A_{2}\right)=\left(m_{0}+m_{7}\right) V_{2}+P_{2} A_{2}$

\subsubsection{Constant area section}

The mixed flow is entered in the constant area section in supersonic velocity conditions. There will be a sudden reduction in velocity and a rise in pressure as a result of the occurrence of normal shockwaves .

The mach no of mixed flow at section 2 after shockwave is

$M_{2}=\frac{V_{2}}{\sqrt{K R T_{2}}}=\frac{V_{1}}{\left(K P_{2} V_{2}\right)^{0.5}}(13)$

This gives $\mathrm{A}_{2}$ as

$A_{2}=\frac{m_{0} V_{1} \eta_{m}}{P_{2}\left(K m_{2}^{2}+1\right)-P_{7} \eta_{m}}$

\subsubsection{Diffuser section}

Diffuser reduces the velocity and thereby increase the pressure of mixed flow

$$
\begin{aligned}
& h_{2}+\frac{V_{2}^{2}}{2}=h_{3} \\
& \eta_{d}=\frac{h_{3 s}-h_{2}}{h_{3}-h_{2}}
\end{aligned}
$$

\subsubsection{Optimum mixing area section}

There is an optimum value of $\mathrm{A}_{2}$ for the defined operating conditions of the ejector flow, which gives maximum entrainment ratio. For optimum $\mathrm{A}_{2}$ the corresponding Mach no and Pressure at section 2 is given by

$$
\begin{aligned}
& M_{2}^{2}\left[1+\left(1-\eta_{d}\right)\left(P_{2} / P_{3}\right)^{K-1 / K}\left(\frac{K}{1+{ }^{P} / P_{2}}-K\right)\right]=1 \\
& \left(P_{2} / P_{3}\right)^{K-1 / K}-\eta_{d} M_{2}^{2} \frac{K-1}{2}=1
\end{aligned}
$$

\section{2 solution procedure}

- $\quad$ Define the design parameters including $\mathrm{Q}_{\mathrm{g}}, \mathrm{P}_{0}, \mathrm{P}_{7}$ and $\mathrm{P}_{3}$.Also input the ejector efficiencies $\underline{\eta}_{\underline{n}}, \eta_{\mathrm{m}}, \underline{\eta_{s}}, \underline{\eta}_{\underline{d}}$

- Calculate the primary massflowrate $\mathrm{M}_{0}$ and velocity at nozzle exit $\mathrm{V}_{1}$

- Calculate machnumber $\mathrm{M}_{2}$ and pressure $\mathrm{P}_{2}$ at section 2 for optimum mixing constant area $\left(\mathrm{A}_{2}\right)$

- $\quad$ Calculate optimum mixing constant area $\mathrm{A}_{2}$

- $\quad$ Assume the value of entropy $\mathrm{s}_{2}$ at section 2 with pressure $\mathrm{P}_{2}$

- $\quad$ calculate enthalpy $\mathrm{h}_{2}$ and specific volume $\mathrm{v}_{2}$

- $\quad$ Calculate enthalpy $\mathrm{h}_{3 \mathrm{~s}}$ with entropy $\mathrm{s}_{2}$ and pressure $\mathrm{P}_{3}$

- Calculate enthalpy $\mathrm{h}_{3}$

- $\quad$ Calculate velocity $\mathrm{V}_{2}$ and also secondary mass flow rate $\mathrm{m} 7$

- Check for $\left|m_{0}+m_{7}-A_{2} \cdot V_{2} / v_{2}\right|$ within a defined tolerance, if not assume a new value of $s_{2}$ and iterate the calculation

- Analyse the system to calculate cooling capacity and COP

\subsection{Model validation}

The mathematical model explained in section 3.1 is validated for entrainment ratio by using published results .The efficiencies of primary nozzle, mixing and diffuser were taken as 0.96,0.87 and 0.88 respectively[20].The comparison is given in table 2. 
Table.2 Validation of vapour ejector model

\begin{tabular}{|c|c|c|c|c|}
\hline Reference & Operating Conditions & $\begin{array}{l}\text { Entrainme } \\
\text { Reference }\end{array}$ & Model & Remarks \\
\hline $\begin{array}{l}\text { Reference[20] } \\
\text { Theoretical }\end{array}$ & $\begin{array}{l}\mathrm{P}_{\mathrm{g}}=5-5 \mathrm{bar} \\
\mathrm{P}_{\mathrm{c}}=2 \mathrm{bar} \\
\mathrm{P}_{\mathrm{e}}=0.8 \mathrm{bar} \\
\left(\eta_{\mathrm{n}}=0.96, \quad \eta_{\mathrm{m}}=0.87,\right. \\
\left.\eta_{\mathrm{d}}=0.88\right)\end{array}$ & 0.22 & 0.227 & $\begin{array}{l}\text { Relative error in } \\
\mu \text { is } 3.1 \%\end{array}$ \\
\hline $\begin{array}{l}\text { Reference[4] } \\
\text { Experimental }\end{array}$ & $\begin{array}{l}\mathrm{T}_{\mathrm{g}}=95^{\circ} \mathrm{C} \\
\mathrm{T}_{\mathrm{e}}=8^{\circ} \mathrm{C} \\
\mathrm{T}_{\mathrm{c}}=32^{\circ} \mathrm{C}\end{array}$ & 0.325 & 0.323 & $\begin{array}{l}\text { Relative error in } \\
\mu \text { is } 0.6 \%\end{array}$ \\
\hline
\end{tabular}

\section{4performance evaluation at off design operating conditions}

The ejector performance modelled in section (3.1) represents its operation at designed pressure and quality(saturated vapour) refrigerant at primary nozzle inlet with defined flow rate. In actual operating conditions the input heat is most likely to vary like fluctuation in solar radiation for the case of solar vapour generator etc. The mass flow rate of primary fluid will be constant as delivered by the pump. I this case when the heat input in the generator is less than the designed value, the quality of primary flow at ejector inlet will not be saturated vapour. it will be a two phase flow. Consequently the performance of ejector and ejector flow need to be evaluated a two phase ejector flow. The two phase ejector in refrigeration systems is mainly used as an expansion device, especially in transcritical $\mathrm{CO}_{2}$ systems(21-23).It helps in those systems to recover the expansion energy loss. In this study two phase ejector is the driving ejector in ERS due to low heat input in the generator

\subsubsection{Two-phase ejector model}

Modelling of the two phase ejector is based on the procedure given by A.A Kohnhauser[24].In this model the circulation ratio $r$ which is the ratio of mass flow rate through the ejector to total mass flow rate in the system is an input variable and is initially assumed. The correct ratio is determined iteratively. The pressure drop in secondary nozzle is assumed to be $2 \mathrm{kPa}$ to get the mixing pressure $\mathrm{P}_{\mathrm{m}}$ for maximum entrainment ratio[25].

Referring to the fig 1, mathematic formulation and procedure for simulation is given below

$\underline{\text { Inputs }}$

$\underline{\eta_{\mathrm{n}}}, \underline{\eta_{\mathrm{s}}}, \underline{\eta}_{\underline{\mathrm{d}}}, \mathrm{p}_{0}, \mathrm{~h}_{0}, \mathrm{p}_{7}, \mathrm{~h}_{7}, \mathrm{r}$

Outlet of motive nozzle

$h_{1 n}=\left(1-\eta_{n}\right) h_{0}+\eta_{n} h\left(s_{0}, p_{m}\right)$

$U_{1 n}=\sqrt{2\left(h_{0}-h_{1}\right)}(20)$

Outlet of suction nozzle

$h_{1 s}=\left(1-\eta_{s}\right) h_{7}+\eta_{s} h\left(s_{7}, p_{m}\right)$

$U_{1 s}=\sqrt{2\left(h_{7}-h_{4}\right)}$

Outlet of mixing section

$U_{2}=(1-r) U_{1 s}+r U_{1 n}(23)$

$h_{2}=(1-r) h_{1 s}+r h_{1 n}-\frac{1}{2} U_{2}^{2}(24)$

$s_{2}=s\left(h_{2}, p_{m}\right)(25)$

Outlet of diffuser

$$
\begin{aligned}
& h_{3}=h_{2}+\frac{U_{2}^{2}}{2}(26) \\
& h_{3}^{\prime}=h_{n}+\eta_{d} \frac{U_{2}^{2}}{2}(27)
\end{aligned}
$$




$$
\begin{aligned}
& p_{3}=p\left(s_{2}, h_{3}^{\prime}\right)(28) \\
& x_{3}=x\left(p_{3}, h_{3}\right)(29)
\end{aligned}
$$

\section{Output}

Output of the simulation model is $\mathrm{r}$ and $\mathrm{P}_{3}$

The relation between $r$ and entrainment ratio $\mu$ is given by[25]

$$
\mathrm{r}=1 /(1+\mu)(30)
$$

The quality of the refrigerant at ejector outlet $\mathrm{x}_{3}$ will be equal to $\mathrm{r}$. The assumed value of $\mathrm{r}$ is compared with the quality at outlet $\mathrm{x}_{3}$ and an iterative calculation is done to get the exact value of $\mathrm{r}$ and entrainment ratio for the specified operating conditions

In this mode of ejector operation where primary flow is inlet at two phase condition in ERS, care should be taken to ensure that the ejector outlet pressure corresponds to the condensing pressure. Two phase ejector flow will result in comparatively lower outlet pressure than a vapour ejector of its kind. I order to ensure the condensing pressure at ejector outlet, the generator pressure is increased for the varying quality of the primary fluid.

\subsubsection{Model validation}

The simulation model for two phase ejector is validated for entrainment ratio and ejector backpressure by

\begin{tabular}{|c|c|c|c|c|c|c|}
\hline \multirow[t]{2}{*}{ Reference/Cycle } & \multirow{2}{*}{$\begin{array}{l}\text { Operating } \\
\text { conditions }\end{array}$} & \multicolumn{2}{|c|}{ Entrainment Ratio $(\mu)$} & \multicolumn{2}{|c|}{$\begin{array}{l}\text { Ejector back pressure } \\
\mathrm{P}_{\mathrm{b}}(\mathrm{kPa})\end{array}$} & \multirow{2}{*}{ Remarks } \\
\hline & & Exp & Model & Exp & model & \\
\hline \multirow{2}{*}{$\begin{array}{l}\text { R704 Trans critical } \\
\text { system.[27] }\end{array}$} & $\begin{array}{l}\mathrm{P}_{\mathrm{p}}=8148, \\
\mathrm{~T}_{\mathrm{p}}=29^{\circ} \mathrm{C}, \\
\mathrm{T}_{\mathrm{e}}=\left(-4.4^{\circ} \mathrm{C}\right)\end{array}$ & 0.615 & 0.653 & 3437 & 3505 & $\begin{array}{l}\text { Relative error in } \\
\mu=6.2 \% \text { and in } \mathrm{P}_{\mathrm{b}} \\
=1.9 \%\end{array}$ \\
\hline & $\begin{array}{l}\mathrm{P}_{\mathrm{p}}=9145, \\
\mathrm{~T}_{\mathrm{p}}=34.4^{\circ} \mathrm{C}, \\
\mathrm{T}_{\mathrm{e}}=(-2.2)\end{array}$ & 0.614 & 0.602 & 3704 & 3842 & $\begin{array}{l}\text { Relative error in } \\
\mu=1.9 \% \text { and in } \\
\mathrm{P}_{b}=3.7 \%\end{array}$ \\
\hline $\begin{array}{ll}\text { R134a } & \text { EERS } \\
\text { system.[26] } & \end{array}$ & $\begin{array}{l}\mathrm{T}_{\mathrm{c}}=40^{\circ} \mathrm{C} \\
\mathrm{T}_{\mathrm{e}}=5^{\circ} \mathrm{C}\end{array}$ & 0.79 & 0.7689 & 380 & 384 & $\begin{array}{l}\text { Relative error in } \\
\mu=2.53 \% \text { and in } \\
\mathrm{P}_{\mathrm{b}}=1.1 \%\end{array}$ \\
\hline
\end{tabular}
using select published results as shown in table 3. The relative error is less than $4 \%$

Table.3 Validation of two-phase ejector model

\subsection{Thermodynamic Analysis of ejector system.}

.The ejector and ejector refrigeration system is analysed considering the following main assumptions

- $\quad$ Steady state operation

- The inlet condition of both primary and secondary flow is saturated vapour in the system analysis corresponding to design operating conditions

- In the off design operation, quality of primary nozzle inlet is two-phase according to the minimum value corresponding to the critical backpressure for condensation in the respective operating conditions.

- The pressure drop and momentum of secondary flow is neglected.

- $\quad$ Fluid properties after mixing in the ejector is uniform for a given cross section.

- Velocity of flow at the outlet of ejector is neglected.

- $\quad$ potential energy terms are neglected in energy equations

Once the ejector performance is simulated the equations for other system components can be obtained by their thermodynamic analysis.

The rate of heat transfer from the condenser

$Q c=m_{3}\left(h_{3}-h_{5}\right)$

Flow in the expansion valve gives 


$$
h_{6}=h_{7}
$$

Refrigeration effect produced in the evaporator

$Q_{E}=m_{4}\left(h_{4}-h_{7}\right)$

Work input to the pump

$W_{P}=m_{0}\left(h_{9}-h_{8}\right)=V_{8}\left(P_{0}-P_{3}\right)$

Coefficient of performance of the system

$$
C O P=\frac{Q_{E}}{Q_{B}+W_{P}}
$$

The mathematical model of the ejector system operation given above is solved using EES software to get the entrainment ratio and cooling effect produced by the system.

\section{4. $\quad$ Results And Discussion}

As mentioned in the introductory section, the aim of this study is to investigate on cooling effect produced by ejector air conditioning system in the operating range of 2 to $5 \mathrm{~kW}$ heat input at $60{ }^{\circ} \mathrm{C}$ to $100^{\circ} \mathrm{C}$. The results of system operating at design and off design operating conditions are evaluated.

\subsection{Design operating conditions}

Fig 2 gives the variation of entrainemnt ratiowith respect to generator temperator.As the temperator varies from $60^{\circ} \mathrm{C}$ to $100^{\circ} \mathrm{C}$ entrainment ratio increases from 0.175 to 0.385 . The critical condenser temperature at generator temperator 100 is $35^{\circ} \mathrm{C}$ which is the design condenser temperature, as shown in figure 3 . The corresponding critical entrainment ratio is 0.385 .It indicates that the geneator temperator should be at least $100^{\circ} \mathrm{C}$ for maximum capacity utilzation for this designed application.Figure 4shows the COP of the system in the corresponding operating range

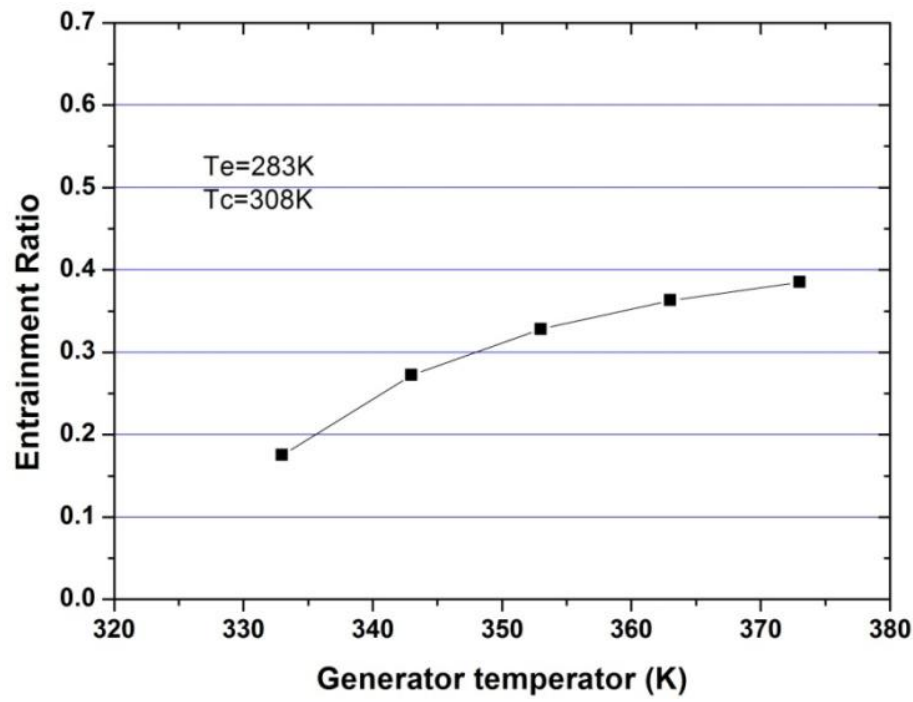

Fig.2- Variation of entrainment ratio with respect to $\mathrm{Tg}$ 


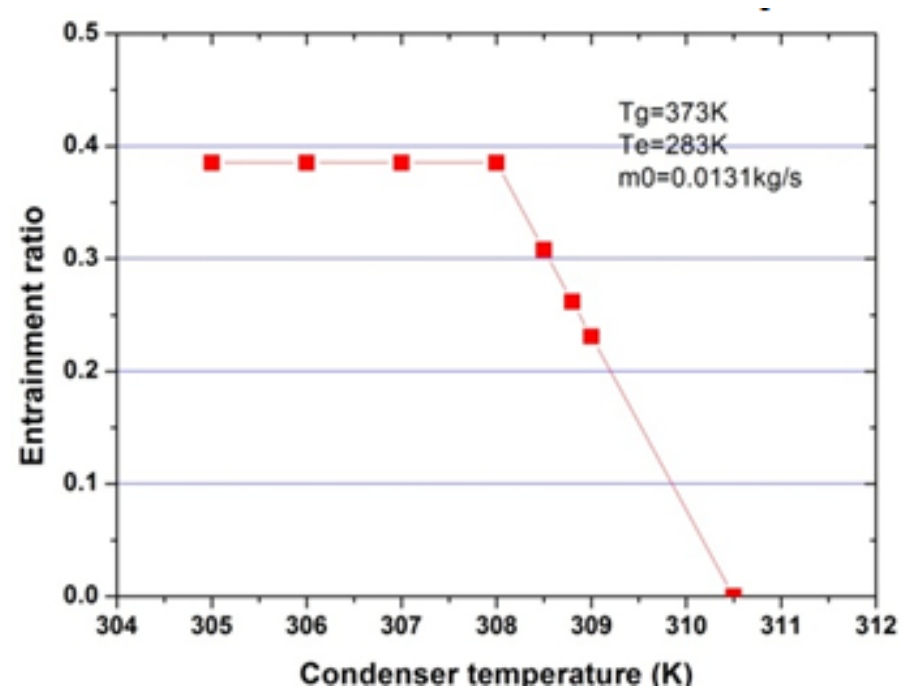

Fig. 3-Critical entrainment ratio at $\mathrm{Te}=283 \mathrm{~K}, \mathrm{Tg}=273 \mathrm{~K}$ and $\mathrm{Tc}^{*}=308 \mathrm{~K}$

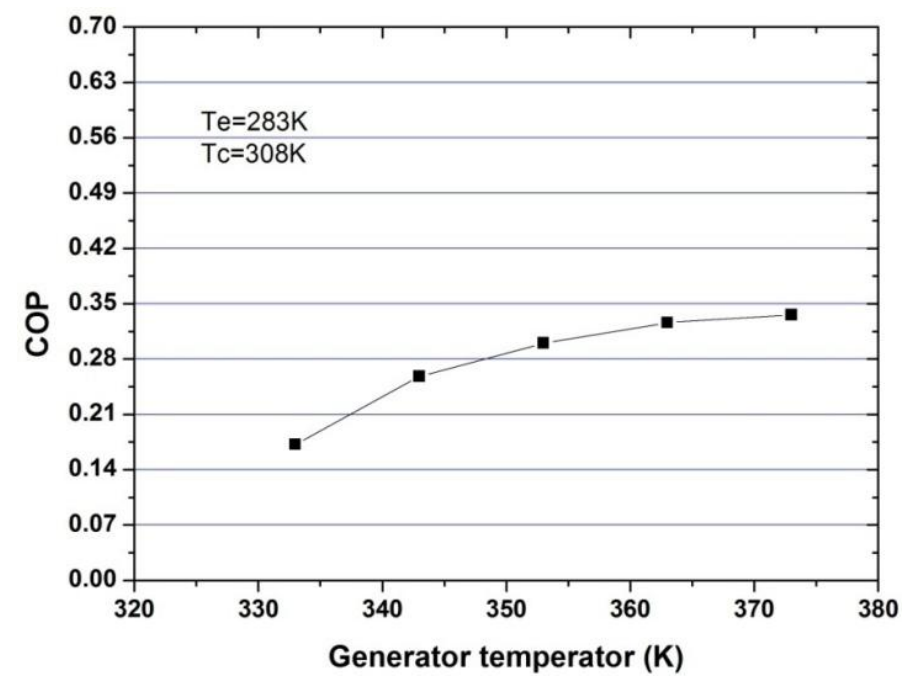

Fig. 4-Variation of COP with respect to $\mathrm{Tg}$

Fig 5 shows the variation of primarymass flow rate as the temperature varies for the given heat input rate of 3 $\mathrm{kW}$ at the generator. Primary mass flow rate decreases from $0.0147 \mathrm{~kg} / \mathrm{s}$ at $60^{\circ} \mathrm{C}$ to $0.013 \mathrm{~kg} / \mathrm{s}$ at $100{ }^{\circ} \mathrm{C}$

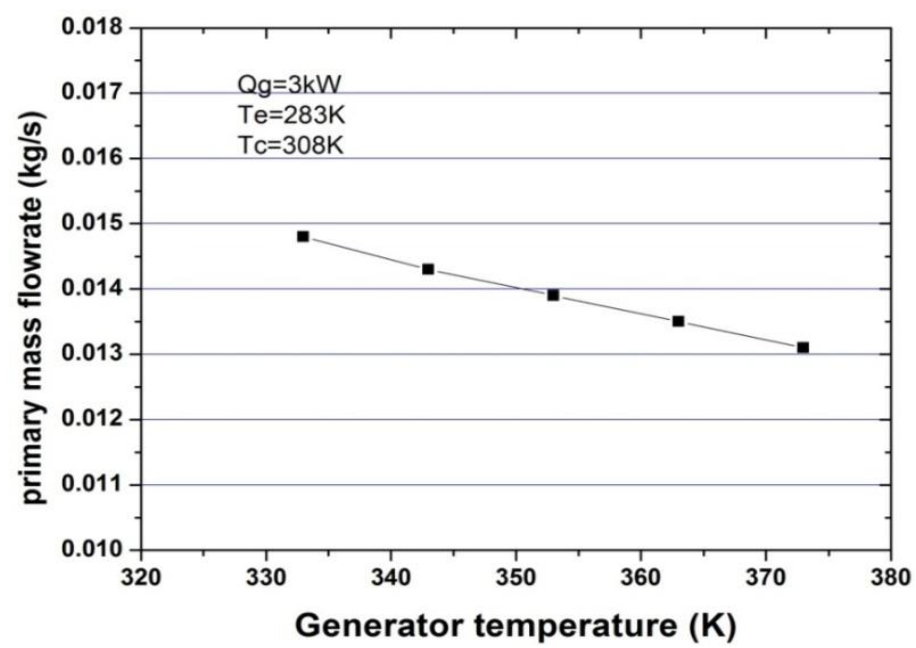

Fig.5-Variation of primary mass flow rate with $\mathrm{Tg}$ atQg $=3 \mathrm{~kW}$ 
Figure 6 shows the cooling capacity of the system under varying heat input and generator temperatures. The maximum cooling produced is $1.7 \mathrm{~kW}$ corresponding to the heat input of $5 \mathrm{~kW}$ and generator temperature of $100^{\circ} \mathrm{C}$

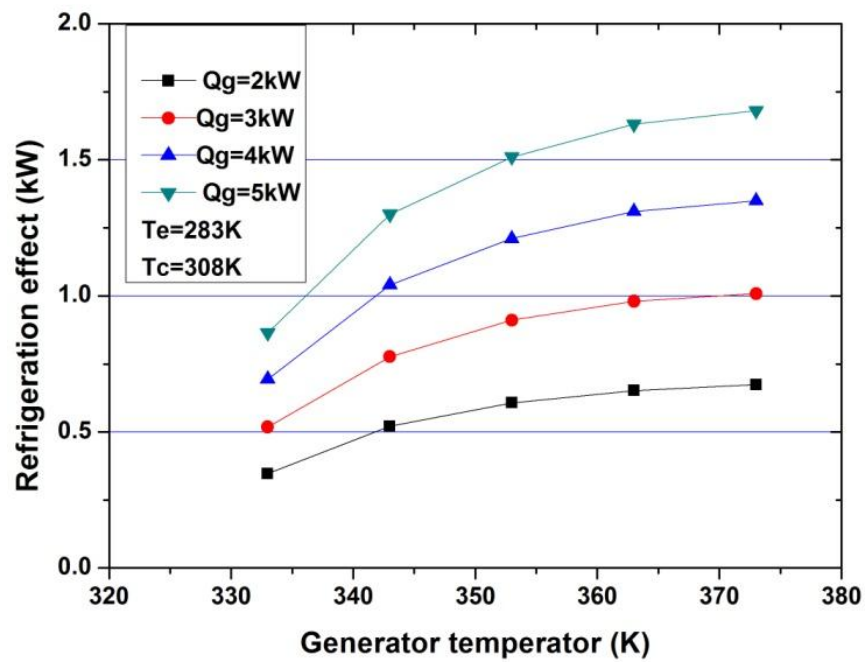

Fig.6-Refrigeration effect produced at different TgandQg

\section{2 off design operating condition}

For a given ejector operating at fixed temperature limits, the reduction of generator heat input rate will lead to unsaturated primary flow in the primary nozzle inlet. Depending on generator temperature there should be a minimum quality of refrigerant at primary nozzle inlet so as to ensure the ejector back pressure corresponding to the condenser pressure. Figure 7 shows the variation of this determining quality along with respective entrainment ratio.

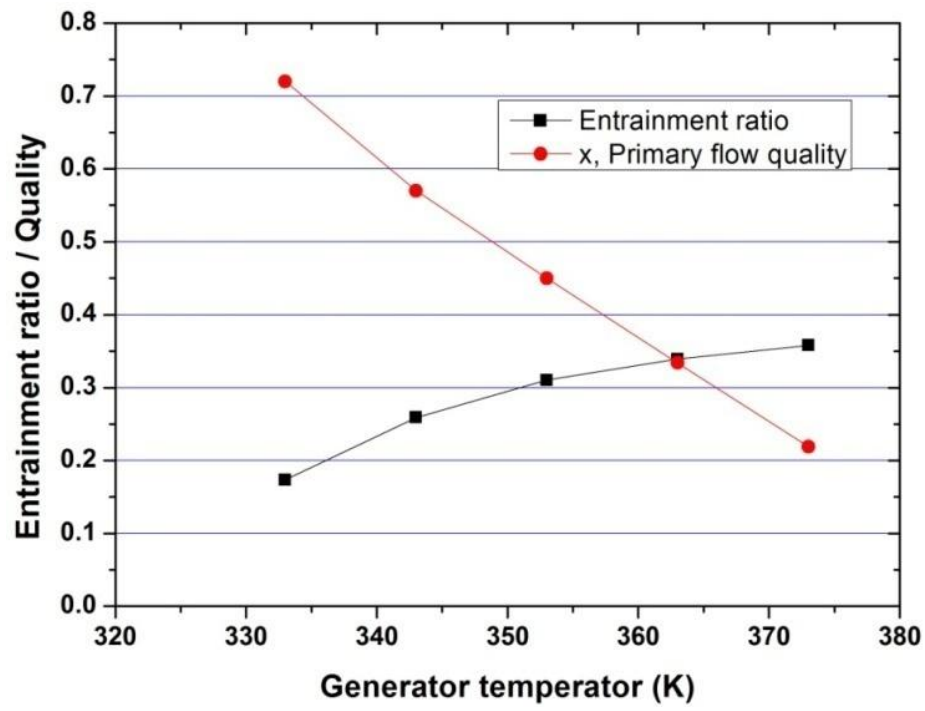

Fig.7- Variation of primary flow quality and correspondingentrainment ratio with $\mathrm{Tg}$ at off design condition

Figure 8 shows the comparison of refrigeration effect produced when the system is at design operating condition versus that at off design condition corresponding to various determining quality. The off design cooling capacity is $12 \%$ lower than design value at $60^{\circ} \mathrm{C}$ and $8 \%$ at $100^{\circ} \mathrm{C}$ 


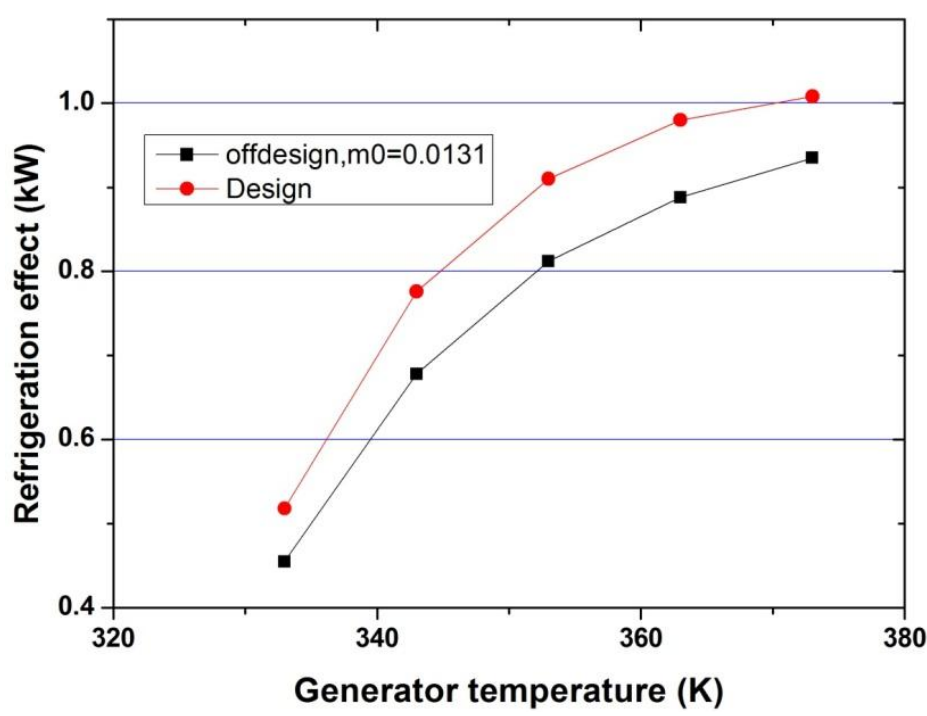

Fig.8- Variation of refrigeration effect with Tg at design and off design operation

It is obvious that the $1.7 \mathrm{~kW}$ cooling produced is not adequate for a typical domestic air conditioning application .The heat input is calculated for the system producing one ton cooling based on the entrainment ratio given in figure7. The results shown in figure 9 suggests that there should be at least $7 \mathrm{~kW}$ heat input when the system is operating at $100^{\circ} \mathrm{C}$. It increases in the subcritical mode operation to a maximum of $18.27 \mathrm{~kW}$ at $60^{\circ} \mathrm{C}$ generator temperature

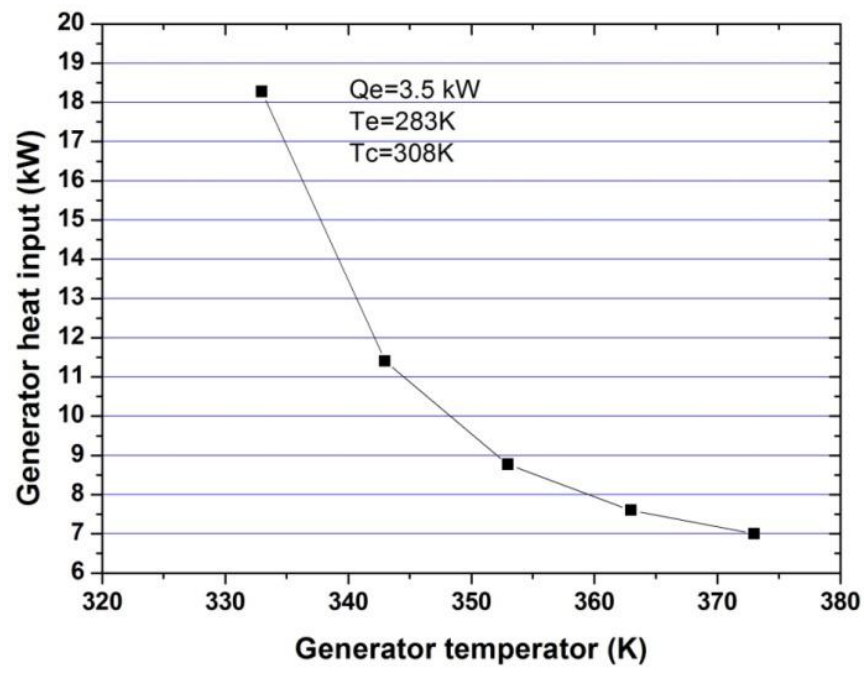

Fig. 9-Variaton of $Q_{g}$ with $T_{g}$ for one ton cooling effect

\section{Conclusions}

A domestic ejector air conditioning system was theoretically analysed to investigate on cooling effect produced when the heat input in the generator varied from 2 to $5 \mathrm{~kW}$ in the temperature range of 60 to $100^{\circ} \mathrm{C}$. Mathematical model of the vapour ejector operating at design conditions as well as the two-phase ejector operating at off design conditions were developed and validated. The model revealed that there should be at least $100^{\circ} \mathrm{C}$ generator temperature to have a critical temperature of $35^{\circ} \mathrm{C}$ in producing $10^{\circ} \mathrm{C}$ cooling. Thus the operation of the system in 60 to $100^{\circ} \mathrm{c}$ temperature range is in subcritical mode of ejector operation. Consequently the cooling produced is quite low ranging from $0.4 \mathrm{~kW}$ at $2 \mathrm{~kW}, 60^{\circ} \mathrm{C}$ heat input to $1.71 \mathrm{~kW}$ at $5 \mathrm{~kW} 100^{\circ} \mathrm{C}$ heat input. In off design mode of operation the heat input is less than required for the designed mass flow rate. Analysis show that the system can produce cooling $8 \%$ to $12 \%$ less than he designed value corresponding to the designed generator temperature. This off design operation is corresponding to a minimum quality of the primary flow at nozzle inlet called the determining quality. Operation beyond the determining quality in the primary nozzle inlet is not possible as condensation cannot take place due to low ejector backpressure.Analysis show that for one ton cooling capacity, the heat input required is at least $7 \mathrm{~kW}$ at $100^{\circ} \mathrm{C}$.This translate to at least $29.1 \mathrm{~m}^{2}$ collector area 
considering $800 \mathrm{~W} . \mathrm{m}^{-2}$ solar insulation and $30 \%$ collector efficiency. This quite not suitable for a domestic application with space constraints.Hybrid vapour compression ejector configurations can be employed to reduce collector area.

\section{Acknowledgements:-}

The authors acknowledge the official support extended by VIT University, India for the conduct of this research.

\section{References}

Giorgio Besagni ,RiccardoMereu and FabioInzoli ,2016, Ejector refrigeration: A comprehensive review , Renew.Sust.Energy,53, 373-407

ZineAidoun, Khaled Ameur, Mehdi Falsafioon and MessaoudBadache ,2019, Current Advances in Ejector Modeling, Experimentation and Applications for Refrigeration and Heat Pumps. Part 1: single phase Ejectors

" , Inventions, 4(15),1-73

K.O. Shestopalov , B.J. Huang , V.O. Petrenko and O.S. Volovyk ,2015 , Investigation of an experimental ejector refrigeration machine operating with refrigerant R245fa at design and off-design working conditions. Part 1. Theoretical analysis ,Int.J.Refrigeration, 55 201-211.

K.O. Shestopalov , B.J. Huang, V.O. Petrenko and O.S. Volovyk ,2015, Investigation of an experimental ejector refrigeration machine operating with refrigerant R245fa at design and off-design working conditions. Part 2. Theoretical and experimental results ,Int.J.Refrigeration,

YingjieXu, Chunyan Wang, Ning Jiang, Mengjie Song, Qin Wang and Guangming Chen , 2019, A solar-heatdriven ejector-assisted combined compression cooling system for multi-storey building - Application potential and effects of floor numbers , Energ. Convers. Manag. 195 , 86-98.

Jin Hua Wang, J.H Wu,S, S Hu and B.J Huang,2009, Pwrformance of ejector cooling system with thermal pumping effect using R141b and R365mfc, Appl. Therm. Eng. 29,1904-1912

SzabolcsVarga, Armando C. Oliveira and Bogdan Diaconu,2009, Analysis of a solar-assisted ejector cooling system for air conditioning, Int.J. Low carbon. Tech,4,2-8

CuneytEzgi and Ibrahim Girgin,2015, Design and Thermodynamic Analysis of a Steam Ejector Refrigeration/Heat Pump System for Naval Surface Ship Applications,entropy,17,8152-8173

K.R. Ullah ,R.Saidur , H.W.Ping, R.K.Akikur , N.H.Shuvo , 2013 , A review of solar thermal refrigeration and cooling methods, Renew. Sust. Energy, 24, 499-513.

A.Allouhi, T.Kousksou, A.Jamil,P.Bruel, Y.Mourad and Y.Zeraouli, 2015 , Solar driven cooling systems: An updated review , Renew. Sust. Energy ,44, 159-181.

A.Gupta ,Y.Anand, S.K.Tyagi and S.Anand , 2016, Economic and thermodynamic study of different cooling options : A review, Renew. Sust. Energy,62, 164-194.

Dan NchelatebeNkwetta and Jim Sandercock ,2016,A state-of-the-art review of solar air-conditioning systems , Renew. Sust. Energy , 60, 1351-1366.

Jianyong Chen, 2014, Investigation of Vapor Ejectors in Heat Driven Ejector Refrigeration Systems, Doctoral Thesis, Department of Energy Technology, Royal institute of technology, KTH, Stockharm, Sweden

YingjieXu, Ning Jiang, Qin Wang, Ning Mao, Guangming Chen and ZengliangGao , 2018 , Refrigerant evaluation and performance comparison for a novel hybrid solar-assisted ejection-compression refrigeration cycle , Solar Energy, 160, 344-352.

S.He,Y.Li and R.Z.Wang, 2009, Progress of mathematical modelling of ejectors, Renew. Sust. Energy,13,17601780

WenxiuHou, Lei Wang, Jia Yan , Xianbi Li and Ling Wang ,2017, Simulation on the performance of ejector in a parallel hybridejector-based refrigerator-freezer cooling cycle , Energ. Convers. Manag, 143, 440-447

J.A. ExpósitoCarrillo , F.J. Sánchez de La Flor and J.M. SalmerónLissén, 2017, Thermodynamic comparison of ejector cooling cycles. Ejector characterisation by means of entrainment ratio and compression efficiency ,Int. J. of refrigeration, 74, 371-384

Jose .M Cardemil and Sergio Clle, 2012, A general model for application of vapour ejectors for application in refrigeration, Energ. Convers. Manag., 64,79-86

B.J Huang,J.MChang,C.Pwang,and V. A Petrenko,1999,A 1-D Analysis of ejector performance, Int. J. of refrigeration, 22,354-364

FahidRiaz, PohSeng Lee and Siaw Kiang Chou, 2020, Thermal modelling and optimization of low-grade waste heat driven ejector refrigeration system incorporating a direct ejector model,Appl. Therm. Eng, 167,114710

ZineAidoun, Khaled Ameur, Mehdi Falsafioon and MessaoudBadache ,2019, Current Advances in Ejector Modeling, Experimentation and Applications for Refrigeration and Heat Pumps. Part 2: Two-Phase Ejectors , Inventions, 4(16), 1-54

Huashan Li, Fei Cao, Xianbiao Bu, Lingbao Wang and XianlongWanga, 2014, Performance characteristics of R1234yf ejector-expansion refrigeration cycle , Applied Energy,121, 96-103. 
H. KursadErsoy and NagihanBilir Sag, 2014, Preliminary experimental results on the R134a refrigeration system using a two-phase ejector as an expander, Int. J. of refrigeration, 43, 97-110

A.A Kohnhauser, The use of ejector as a refrigerant expander,1990, in: International Refrigeration and Air Conditioning, Conference., Purdue university,1990, Paper 82

Xiao Wang and Jianlin Yu, 2016,An investigation on the component efficiencies of a small two-phase ejector, Int. J. of refrigeration, 71, 26-38

N. BilirSag , H.K. Ersoy , A. Hepbasli and H.S. Halkaci, 2015, Energetic and exegetic comparison of basic and ejector expander refrigeration systems operating under the same external conditions and cooling capacities, Energ. Convers. Manag, 90, 184-194.

Jose M. Cardemil and Sergio Colle, 2012, A general model for evaluation of vapor ejectors performance for application in refrigeration, ,Energ. Convers. Manag, 64, 79-86 